\title{
Present status and future scope of floriculture industry in Sri Lanka and its potential in women empowerment
}

\author{
Padmini, S. M. P. C. ${ }^{1 *}$ and Kodagoda, T. D. ${ }^{2}$ \\ ${ }^{\prime}$ Sri Lanka Council for Agricultural Research Policy, Wijerama Mawatha, Colombo, Sri Lanka. \\ ${ }^{2}$ Department of Human Resources Management, Faculty of Management and Finance, University of Colombo, Colombo, Sri Lanka.
}

\begin{abstract}
Floriculture industry is considered a high income generating agribusiness and it can potentially be harnessed as a means of socioeconomic development in Sri Lanka. Limited literature and lack of data are the main barriers to develop policies in this sector. The business is handled by a few exporters, middle level growers and small scale growers. The National Policy Framework of the Government of Sri Lanka (2010) aimed to develop the floriculture sector as a source of income generating pathway to unemployed women in the country.
\end{abstract}

The observation and analysis presented in this paper is based on a survey conducted during April - August 2014 in Colombo and Gampaha Districts of Sri Lanka and views of growers obtained in the workshop on "Setting new horizons in horticulture 2020" held on $30^{\text {th }}$ January 2015 in Colombo. Data were collected for qualitative analysis through direct questions and open ended questions. The findings of this study acknowledge that the collective actions of growers drive the development of floriculture in the country. Indirectly, growers highlighted that increase in the utilisation of flowers and indoor plants in the country has created a favorable demand for their products and therefore, growers need to expand their operations. The main constrains of the growers were financial difficulties and high cost of land to expand their productions. Growers as well as the government need to develop a proper market for floriculture products at national and international levels in par with other export agricultural crops in the country.

Keywords: Floriculture industry, institutional framework, flower growers, Sri Lanka.

\section{INTRODUCTION}

Sri Lanka is home to an enormous botanical diversity and has a wide range of floricultural species. Floriculture is a high income generating agribusiness and it can potentially be harnessed as a means of socioeconomic development in Sri Lanka. Great opportunities exist, especially for women growers. The Government of
Sri Lanka is planning to establish 1,500 floriculture villages and generate 30,000 jobs in sub urban and rural areas (National Policy Framework, 2010). Many supporting networks have been developed by government agencies and non-government organisations to provide training, planting materials and infrastructure facilities to empower women floriculture growers.

Uses of flowers in the country are increasing with the development of higher living standard of Sri Lankans and flowers are used in many events of life such as for greetings, weddings and funerals as well as in religious functions, mainly of Buddhists and Hindu faith. Most perfumes used in the world are from oils of Jasmin and Roses, besides flowers plays a vital role in human life by improving the environment and as a symbol of sentiments (Zeb et al., 2007).

Sri Lanka earned around rupees 14.0 billion in year 2014 by exporting floriculture products. However, growers informed that they earn profits by selling their products locally compared to exporting cut flowers. Limited availability of literature and lack of data are the main barriers to develop policies in this sector. The business is handled by few exporters, middle level growers and small scale growers. The National Policy Framework of the Government of Sri Lanka (2010) aimed to develop the floriculture sector as a source of income generation for unemployed women in the country. Sri Lanka is recognised internationally as one of the best quality floriculture production centers in the world. The National Policy Framework aimed to increase per capita income to US\$ 4,000 per annum of an average Sri Lankan worker, modernisation of lifestyle and increase the quality of life. The policy framework also planned to establish 1,500 floriculture villages and generate 30,000 jobs in suburban and rural areas 
of Western, North Western and Central Provinces of Sri Lanka. Therefore, this research examines the present status of the floriculture industry in Sri Lanka and future needs.

\section{LITERATURE REVIEW}

Sri Lankans frequently use flowers in religious places such as in Buddhists and Hindu temples. Sudhagar (2013) noted that Sri Lanka is one of the importers of Indian floriculture products. Sri Lankans import Jasmine flowers from India to conduct Jasmine flower ceremony (Pichcha mal pujawa) in the holy place of Buddhist at Anuradhapura "Jaya Siri Maha Bodhi". Subsequently, the Department of National Botanic Garden and Department of Agriculture jointly established a programme to cultivate Jasmine in Sri Lanka to fulfil the demand. In addition, the development of the tourism industry and service sectors in the country, have generated high demand for floriculture products for indoor decorations. Floriculture creations are also available in e-markets through websites, the most common example being "Lassana Flora website". Many beauty culture therapists and Health Spas also use flowers for many therapeutic techniques. Padmini (2014) noted that flowers were also used during ancient times in Sri Lanka and is most evident in the frescoes with flowers on the Sigiriya Rock. It is a symbolic gesture in a painting; no quantitative evidence exists on use of flowers in historic times. Even at present no quantitative evidence of flower usage by locals is available.

The 1997 survey on the floriculture industry of Sri Lanka conducted by Ministry of Agriculture mainly focused on floriculture exporters. Lack of air freights, financial assistance and lack of new varieties for export market were major issues at that time. The 2006 survey on small and medium-sized floriculture entrepreneurs in Sri Lanka, carried out by Sri Lanka Council for Agricultural Research Policy, mainly focused on status of the floriculture sector in Sri Lanka (Niranjan \& Gunasena, 2006). They highlighted limited technical knowledge, lack of locally produced novel varieties, high cost of production, post quarantine checking, market related issues, limited land for expansion as some constraints for the expansion of the floriculture Industry.

\section{Women empowerment}

Women play a major role in Sri Lankan agricultural sectors such as in tea, rubber, paddy and horticultural crops such as fruits, vegetables and floriculture. Labour Force Survey (2012) by the Department of Census and Statistics in Sri Lanka noted that the unemployment rate $(6.2 \%)$ among women was higher than among men $(2.8 \%)$. Economic and social statistics of Sri Lanka (2013) recorded that female migration had increased again up to $49.1 \%$ from total migration $(137,151)$ for employment and of this, $42.3 \%$ are employed as housemaids. As per the development goals in Sri Lanka, to reduce poverty, the gender gap in employment should be minimised by empowerment of women (Kodagoda, 2013).

Research shows that social identities of women entrepreneurs in Sri Lanka are supportive for them to enter international markets (Hewapathirana, 2011). The Government of Sri Lanka and non-government organisations support them to start small and mediumsized businesses to reduce poverty. As a result, many unemployed women and housewives start small floriculture nurseries. Compared to other crops, the income per unit land area is higher in floriculture nurseries. There is no reliable national data in Sri Lanka on the total number of stakeholders engaged in the floriculture sector and major issues of this sector.

Women achieve success in networking because they can practice non-traditional leadership styles (Rosener, 1990). Women have abilities and preferences to develop social networks which act as facilitators for exchanging resources among networks (Renzulli \& Aldrich, 2000). Women workers in Colombia's cut flower industry demonstrate that social capital of individuals, including their employees, relatives and solitary networks are important for property acquisition and intra-household bargaining processes (Friedemann-Sanchez, 2006).

In Sri Lanka, supporting networks are not organised properly to market floricultural products nationally and internationally. Support is provided without considering marketing channels and what they require.

According to literature, community based development and cooperative development are mainly due to increased trust between community members and collective actions known as 'social capital' (Janssens, 2010). Social capital refers to the trust and shared norms of behavior that arise within informal social networks and influences the resources that an individual can mobilise through social networking (Janssens, 2010; $\mathrm{Ju}$ and $\mathrm{Fu}, 2012$ ). Janssens (2010) highlighted that women empowerment and social capital enhanced the development of roads, schools and bridges in the state of Bihar in India. Bihar is one of poorest states of India where a majority the lower castes live. Ju and Fu (2012) analysed many social capita theories and highlighted that social capital is the strength of the team. The best example for the use of social capital is the case of Jasmine growers 
in Karnataka state, India. Cnaan et al. (2014) explained that there are several lessons that can be learned from this successful community enterprise that provides thousands of households in the region with a guaranteed income from Jasmin production.

\section{Global floriculture industry}

Netherlands is the largest floriculture producer of the world and it is a highly mechanized and specialized industry. They heavily use fossil fuels, borrowed capital, chemical fertilizer and pesticide (Hulst, 2012). The global floriculture industry is mainly concentrated to developed countries and has an annual growth rate of $8-10 \%$. More than 120 countries are involved in this industry. Main exporters are Europe and America, Middle Eastern countries, Colombia and Ecuador (Ghule and Menon, 2013; Reid et al., 2009). The Canadian floriculture producers export their products to American markets. The U.S. floriculture industry has a dual market structure, consisting of large scale producers, who can supply the "big boxes" and compete effectively with foreign imports, and small scale producers who have to carve out local markets through higher quality customer service and/or being responsive to specialized consumer demands (Reid et al., 2009). South African floriculture industry employs more than 17,500 people and provides opportunities for rural employment and shows potential for supplying the international market (Matthee et al., 2014). Research conducted using members of the South African Flower Export Council explained their short comings as: the lack of commitment to exporting (they export only a small percentage of their total sales), poor participation in international floriculture programmes, and failing to differentiate or add value to their products. They need to shift their focus from the domestic market and become more export-oriented, as the domestic market is slowly becoming saturated and its turnover is less compared with that of the global market (Matthee et al., 2014).

Colombia is the second largest producer of fresh cut flowers in the world and the main supplier to the United States and the fourth largest supplier to Europe. Reasons are ample land, better environment, low labour salaries, and low shipping cost to the European Market (Miller et al., 2012). Kenya also produces fresh flowers to the European market and similar to Colombia, favourable weather condition and low shipping cost help to earn more income. However, in both countries, the floriculture companies are owned by Europeans and those who work in these companies obtain low salaries (Miller et al., 2012). European investors have also invested in rose farming in Ethiopia and more than 90,000 jobs have been created around the flower farms (Janko and Alemu, 2014).

However, case studies in India show that the floriculture industry helps improve socioeconomic development of tribal women in the harsh dry lands of west India by developing social capital among them (Agoramoorthy and Hsu, 2012). Also, Jasmine growers of the costal Karanataka in India highlighted the use of social capital to eradicate poverty in rural villages (Cnaan et al., 2014; Handy et al., 2011). In Pakistan, the floriculture business is concentrated among small growers and mainly in cities such as Karachi, Lahore and Islamabad. The increasing demand for flowers has led to an increased return on investment (Manzoor et al., 2001). Floriculture in Philippines is becoming a highly profitable industry with improvement of the standard of living. Higher use of floricultural products in hotels and restaurant and the influx of tourists created more marketing opportunities and higher profit for small scale growers (Garcia, 2013). The Philippines government imported some cut flowers to cater the domestic demand for flowers although the country also has strengths for cut flower production. Garcia (2013) has highlighted the existence of a very active horticulture association as an important factor of the improvement of cut flower production in the Phillippines.

Wei et al. (2013) highlighted that the global floriculture market was huge and the floriculture industry has the potential to be used to empower women. Research findings in Papua New Guinea indicated that women play a major role in the floriculture industry with the help of supporting networks.

Mathur and Pachpande (2013) noted that income per unit land area is higher in floriculture compared to cultivation of fruit and vegetables. Income obtained from roses was Indian Rupees 8.4 lakhs / hec while the income from fruits, vegetable and rice was Indian Rupees $20,000 /$ hec, $15,000 /$ hec and 10,000/ hec, respectively. Mou (2012) also indicated that in Bangladesh, the gross margins of flowers and vegetables cultivation per hector were Tk. $1,359,824.20$ and Tk. 46,362.14, respectively. Hernandezl et al. (2013) reported that socio economic conditions in the floriculture sector in Tabasco, Mexico was less developed and returns from floriculture was lower than other crops such as papaya (US\$ $936 /$ hec from floriculture and US\$ 9,332 from papaya) because the floriculture sector in Mexico is in its primary stage and a lot of improvements still need to be made.

Accordingly, the main objective of this study was to identify the present status of floriculture industry in Sri Lanka with emphasis on the role of women in the 
local floriculture sector.

\section{SAMPLE SELECTIONAND METHODOLOGY}

Observations and analysis presented on this paper is based on a survey and interviews conducted during April - August 2014 at Colombo and Gampaha Districts of Sri Lanka and growers views obtained during the workshop on "Setting new horizons in horticulture

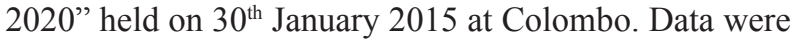
collected for qualitative analysis by direct and open ended questions.

Data were collected from hundred floricultural growers and samples were selected randomly. Interviews were aimed at gathering information on constraints such as; finance, land, technology, planting materials, institutional supports and other factors.

The existing questionnaire in the report of small and medium floriculture entrepreneurs-2006 (Niranjan and Gunasena, 2006) was used with some modification and the mixed method, as noted by Rao and Ibanez (2005). The validity and consistency of the questionnaire can be checked using reliability analysis and coefficient of Cronbach ' $\alpha$ ' value of higher than 0.7 is taken as the minimum acceptable value of reliability. The coefficient of Cronbach $\alpha$ is 0.79 in this questionnaire.

Colombo and Gampaha Districts are in the Western Province of Sri Lanka, situated $06^{0} 56$ North and $79^{0} 51$ East. These two districts were selected due to their high population and the presence of higher number of growers attributed to the availability of infrastructure facilities for exporting and a readily available local market. The total population of these two districts is 2.3 and 2.29 million, respectively. According to the Department of Census and Statistics, around $21.4 \%$ of the total Sri Lankan population is concentrated in these two districts. The populations in these two districts mainly depend on public and private sector occupation but only $3.5 \%$ and $6.7 \%$ of the population in Colombo and Gampaha districts depend on agriculture (Annual Labour Force Survey, 2012).

The surveyed data presented in Table 1 highlight that a majority of the growers ( 88 nos.) had continued their business for more than five years. From this sample 35 growers earned more than Rs. 40,000.00 per month from floriculture businesses and 70 growers were less than 50 years of age while 79 of them had qualified GCE-A/L.
Table 1: Overviews of the sample of women floriculture growers

\begin{tabular}{lcccc}
\hline $\begin{array}{l}\text { Number of } \\
\text { years engaged } \\
\text { on Floricultural } \\
\text { business }\end{array}$ & $\begin{array}{l}\text { Number } \\
\text { of } \\
\text { growers }\end{array}$ & $\begin{array}{l}\text { Income } \\
\text { more than } \\
\text { Rs 40000. } \\
\text { 00 per } \\
\text { month }\end{array}$ & $\begin{array}{l}\text { Age }<50 \\
\text { years }\end{array}$ & $\begin{array}{l}\text { GCE-AL } \\
\text { qualified }\end{array}$ \\
\hline 1-5 years & 12 & 3 & 10 & 8 \\
\hline 6-10 years & 48 & 22 & 40 & 37 \\
\hline $11-15$ years & 22 & 9 & 8 & 20 \\
\hline $16-35$ years & 18 & 1 & 2 & 14 \\
\hline
\end{tabular}

Data showed that a majority of growers (82 nos.) cultivated anthurium which included "Lady-J" varieties and other anthuriums (Figure 1). Most of them had large collections of mother plants which they multiply and sell as potted plants at the local markets by organising exhibitions. Some growers sell their anthurium plants to exporters as well as to local collectors. Growers also said that they earned a good income by selling anthurium flowers at the local markets such as hotels and florists too.

Figure 1: Main cultivated plant types by growers

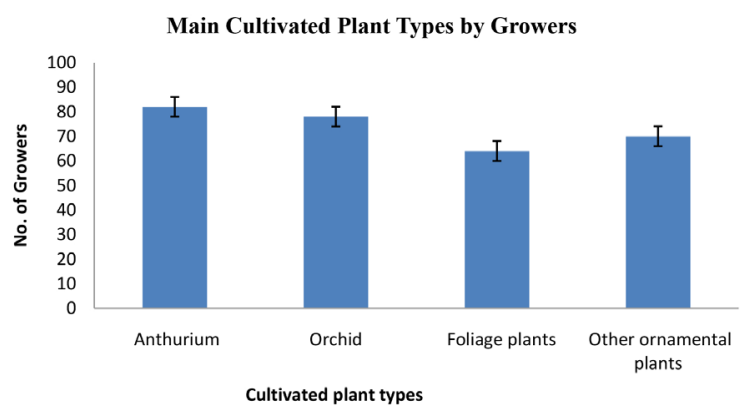

Orchids are mainly grown for the local market and flowers are sold to florists, indoor decorators and hotels. Growers always cultivate a range of varieties according to their interest and market demand. Chrysanthemums, Bougainvilleas, Gerbera and Marigold are the other common species available with growers. Some growers collected seed from foreign contacts and developed mother stocks. Therefore, many new cultivars were available with them. They reported that these new cultivars could be sold at higher prices in local markets; they normally sold these plants for around Rs. 2,500 5,000 .

According to the survey, all growers sold their products as potted plants because they earn a higher income from potted plants than cut flowers and cut leaves. According to growers involved in the survey, the difference between potted plants and rooted plants is 
rooted plants are bigger in size and presented in large pots of around $20-50 \mathrm{~cm}$ of height. Very few growers (4\%) were involved in the production of cut leaves because demand for cut leaves was low in the local market. Those who produce cut leaves supply their produce to exporters as sub-contractors.

The study showed that mainly associations of women growers with supportive networks perform better than others. Results revealed that they had strong links with grower societies and government institutes. The main grower societies are "Suwahas mal", "Liyaabiman" and "Mahim". However, other small groups also do their growing activities with a few members. Many of them appreciate government support. Growers informed us that they obtained technical knowhow, planting materials and shade netting from the Department of National Botanic Gardens, Department of Agriculture and Ministry of Economic Development. Growers who have links with export companies were reluctant to inform name of the companies to which their products were sold. Two growers sent their products to the European market in small scale since they had relatives abroad and were able to develop direct links with them. They show zero links with transport companies and very few links with packaging companies.

Most growers obtained benefits through supportive networks and some societies conduct floriculture exhibitions in common market places once or twice a week. They received free $10^{\prime} \times 10^{\prime}$ canopy huts and space in the city to conduct floriculture exhibitions cum plant sales. The rental for the land was paid by the Department of National Botanic Gardens or Ministry of Economic Development. This promotion is very important to develop and promote the utilisation of floriculture products among the public and it is also a very good motivation for the small scale growers to promote their products. In this sample 35 growers earned more than Rs. 40,000.00 per month from floriculture products and nine growers out of them did not have links with export companies or exporters. They only sold their products in the local market and earned more than Rs. 40, 000.00 per month.

However, women growers explained they encountered constraints in this sector when they decided to expand their businesses. According to the study's findings, $61 \%$ of growers had financial constraints and $68 \%$ of growers had land constraints to expand their businesses. These women growers mostly used family labour (99\%) for this business and most of them stated that they started this business as a hobby and subsequently converted it into a family business venture.

\section{Qualitative analysis}

In the process of interview, growers explained constraints they faced and proposed new strategies to develop this sector. This information provided by growers is included here to help to develop further research on this sector as well as to be used in the development of policies for the improvement of small scale floriculture enterprises.

\section{Transportation}

"Our main problem is the transportation of potted plants to exhibition centers. Even if I hire a vehicle it is not easy to transport all in one trip, but if I make several trips, it will not be profitable."

"We share one lorry to transport our plants to exhibition but we can't take all what we produce. Therefore we can't get maximum profit for what we produce."

Accordingly, they strongly highlighted that cost of transport of their products to the markets or exhibition centers was very high when they hire private transport. Many of them share the lorries but it created issues in selling a higher number of their products. They proposed if the government and banks initiate a financial assistant programme to solve this matter by facilitating provision for tax free vehicles, it would be greatly helpful for the success of their business.

\section{Financial constraints}

Financial constraints are a crucial factor in this industry, unlike in other agriculture sectors. Financial institutes such as banks may not be willing to provide credit to this sector. Available loan facilities are very limited for floriculture expansion programmes. Therefore, growers suggested that they need to have a proper establishment and efficient marketing system similar to other agriculture sectors.

"When we ask for loan facilities from banks, they required proper bank records and proper income source to repay the loan. Our market system didn't show a continues income, therefore, we are unable to keep proper records with banks, therefore we face a lot of difficulties when we need financial assistance to expand our business"

The present local market is highly dependent on exhibitions in cities but the rental for land is very high in such places and small scale growers can't afford the price. Therefore, they suggest development of separate places to conduct their exhibitions with proper advertising, transport and other infrastructures. They further suggest 
a separate institute for research and promotion of floriculture products in local and international markets, similar to the tea sector in Sri Lanka.

Many growers like to learn "home tissue culture" technologies and like to develop small scale laboratories. They are also willing to learn new technologies on packaging, post-harvest management, extension of vas life at retail markets and international market conditions.

"If an institute could provide training on tissue culture, packaging and post-harvest handling, those are very valuable for us. It will help us to produce more market products and new varieties too."

Some of them indicated that, they had obtained mother plants and some equipment from supportive networks but subsequently no one had monitored their progress. They said that they were willing to be evaluated at regular intervals so that they can judge their progress for themselves and explain constraints, at the same time. They further suggested development of appropriate government policies along with assistance package to further improve this sector and minimise the risk associated with this industry.

In the the workshop on "Setting new horizons in

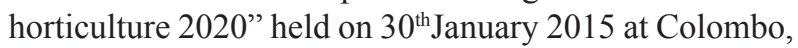
exporters highlighted the following;

"To develop evidence based policy decision, correct data is important in this sector, therefore regular monitoring of the progress by way of surveys is highly important to identify direct and indirect involvement of this sector. Further to that, establishment of a National Floriculture Council is also important to develop more export markets, research and developments and to open new avenues to develop the use of floriculture products."

Another exporter highlighted the barriers they faced when they export their floriculture products as follows;

"There is an urgent need to develop infrastructure facilities such as cool room facilities, Rapid checking etc. at the Katunayake Airport, to prevent the loss of product quality when products were kept in long duration at room temperature until it is loaded to the plane."

Many growers suggested establishing a separate research institute for the floriculture sector for following reasons;
"At present we do our experiments in collaboration with universities to find solutions for pest and disease problems and germination problems but if we can have separate institute for this purpose it can be highly valuable to improve this sector."

The findings of this research also proved this necessity and some growers were very keen to share their knowledge with us. As Ju and Fu (2012) noted in their research, trust is one of the important measures of social capital indices and they developed a questionnaire to evaluate social capital in the research team. They also explained structural social capital such as vertical and horizontal trust in group, respectively measured by colleagues trust and leaders' trusts.

\section{DISCUSSION}

The large proportion $(60 \%)$ of the sample is in the less than fifty years age group. This shows most of these women growers are in their energetic age to do business activities. This is one of the reasons; why they could properly utilise the support services and facilities offered by the institutes. The other most important feature is that $79 \%$ of these growers had qualified GCE-A/L, assuring higher literacy level and the ability to understand new technologies easily. This is very important when they engaged in the export industry, since this market demands very high hygienic standards and high quality products within a short time period. Time target and quantity of products development is very important in this type of a sophisticated market. The sampled women growers produced high quality products within a short time period for the local market and they requested government assistance to source the export market as well.

In this sample, 09 growers earn more than Rs. $40,000.00$ per month from floriculture products by selling their products only at local markets. Most of the exporters send cut leaves to international markets but the small scale women growers did not cultivate cut foliage plants; only 4 growers cultivated cut foliage plants. This indicates that sampled growers do not show links with cut foliage exporters and associations. They should consider establishing links with exporters to explore foreign market options.

Findings of the study revealed that all the growers sold potted plants and many were also producing cut flowers to local and international markets. In the winter season Europe sinks in snow and more cut flowers are imported from Sri Lanka, Iran, India, Pakistan etc. (Zeb et al., 2007). Sri Lanka has direct airlines to European market destinations facilitating the export of floricultural 
products within a considerably short time. Other than that, many cut flowers and cut leaves are exported to non-European markets such as Japan, Dubai, Maldives etc. Rooted plants are mainly produced for indoor decorations and growers sell those products to interior decorators.

With guidance of the Department of National Botanic Gardens and Ministry of Economic Development, growers are encouraged to join flower grower's associations such as "Suwahasmal" and "Liyabiman", respectively. Large portions of government assistance were channeled through these societies and market places were also created to conduct flower exhibitions. These programmes initiated and popularised utilisation of floriculture products within the country as well. With economic development of the country people spend money for happy occasions of life as in developed countries and as a result utilisation of floricultural products is also increasing (Garcia, 2013). Within these societies, growers have their small groups and try to export their products, exchange their knowledge and do collective works to market their products. The evidence of this research acknowledged that a collective action of growers drives development of social capital in the society.

$\mathrm{Ju}$ and $\mathrm{Fu}$ (2012) reviewed theories of social capital and explained that there was no general definition about social capital but three theories are noted as follows; (a) social capital contains three components; resource embedded in social structure, the persons' capability to use the resource and through the objective ability to use or mobilise these resources (b) social capital as the sum of the potential and real resource embedded in the network owned by individual or organisation, (c) social capital as contact between the main body and society, the capability to access resource through the contact. Munasib and Jordan (2011) viewed social capital as community involvement and farmers used it as sustainable agricultural practices. This study evaluated the linkages of growers with supporters to improve income of rural women and reduce poverty of rural families. As per the literature, Rao and Ibanez (2005) explained a causal and positive impact of social funds on trust as well as on collective action and better educated and better networked individuals got more benefits from the social funds.

Social capital is defined as informal forms of relationships with organisations, networks and associations and it helps to share knowledge, mutual trust, social norms and unwritten rules (Shoji et al., 2012). Social capital plays a vital role to reduce poverty and facilitate rural development (Shoji et al., 2012; Uphoff and Wijeratne, 2000). Fafchamps and Minten (2000), convincingly described that social capital helps to earn high profits in trade by reducing transaction cost, also helps to solve the enforcement of poorer in rural area. Shoji et al. (2012) studied the social capital investments in Sri Lankan farmer societies and noted that, expenditure toward community ceremonies, participation in community work (Shramadana), and participation in communal irrigation maintenance as examples for the utilisation of social capital for the development of rural farmer communities.

Interaction with each other is essential for the success of a business and few studies indicated that those networks helped the emergence of organisations as cooperatives etc. (Newbert and Tornikoski, 2012). Close interaction within groups with the same objectives leads to the development of cooperatives societies (Matthew et al., 2012). Empowerment of women is very important in developing countries because their participation is very important to the socio-economic development of the country (Noreen, 2011). Normally the networking abilities of women are very high and that leads to form self-help groups (Rani, 2014).

However, unlike floricultural networks in other countries, the local growers did not connect with services like transport agents; and most of them sell their products directly. Only $39 \%$ of growers had links with financial institutes and they informed that, having financial facilities from banks and transport facilities, would be highly helpful to improve their businesses. However, growers used social capital in a productive manner to improve the floriculture sector in the country. This situation is common in a Sri Lankan context, because in other agricultural practices such as paddy cultivation, and tea, social capital was used to reach success in their production systems.

Main constraints for growers were the lack of financial and transport facilities to expand their productions as many growers start their business at home garden level and with success at that level try to expand their floricultural productions to commercial level. Some growers overcome such problems by working collectively. However, due to poor recognition of the floriculture industry by finance institutes, there is a reluctance to grant loans to growers unlike in other agricultural sectors such as tea, coconut and paddy. Another problem is that the floriculture industry is new to the country and not properly established yet. Therefore, growers as well as the government needs to work together to develop proper production, transport and 
marketing facilities for floriculture products nationally and internationally. Therefore, institutional support is very important to promote this industry.

The results of the study showed that the development of social capital with supportive networks improved income of the women floricultural growers as some of them earned more than Rs. 40,000.00 per month. With favorable environmental conditions and biodiversity available in the country, floriculture in Sri Lanka has a high potential to be further developed, attracting more women to engage in this industry.

\section{CONCLUSION}

The findings of this research highlighted that collective actions of growers drive the development of floriculture sector in the country. Indirectly growers also highlighted an increase in utilisation of flowers in the country, assuring good market potential and the need for expansion of the floriculture sector.

The main constrains of the growers are the lack of financial support and land availability to expand their production as many growers start their business at home garden level and with the idea of expanding it subsequently, depending on their success. However, with poor recognition of the industry, many financial institutions are reluctant to grant loans to floriculture industry. Another problem is that the floriculture market is new in the country and is not properly established. Therefore, growers as well as the government need to develop proper marketing channels for floriculture products, nationally and internationally, similar to tea cultivation in the country. Tea cultivation is also distributed in seven districts of the country, hence the government established seven government institutes to promote, market and to conduct researches. Therefore, institutional support is most important to promote the floriculture industry. This was also indicated by growers at the interviews.

With favorable environment and biodiversity in Sri Lanka the floriculture industry has more potential to develop and more women can engage in this industry leading to reduced social problems among women. However, more government assistance is needed to establish this industry in a proper manner and institutional establishment is very important to govern the sector and further develop research and marketing aspects of floricultural products. Finally, keeping in view of the above points, more support has to be provided to these growers to transport of their products and assistance is needed to find better market opportunities and to reduce financial and lands constraints.

An institutional framework is a crucial need to establish and expand the floricultural industry in Sri Lanka. Accordingly, comprehensive research is very important for further development of this sector in the country.

\section{REFERENCES}

Agoramoorthy, G. \& Hsu, M. J. (2012) Impact of floriculture development enhances livelihood of India's rural women, Journal of Agriculture and Rural Development in the Tropics and Subtropics, 113(1), pp: 69-76.

Cnaan, R. A., Ganesh Bhat, G., Meijs, L. C. P. M. \& Handy, F. (2014) You reap what you pick, Journal of Enterprising Communities: People and Places in the Global Economy, 8 (2), pp: $86-102$.

DOI: https://doi.org/10.1108/jec-11-2012-0058

Fafchamps, M. \& Minten, B. (2002) Returns to social network capital among traders, Oxford Economic Papers, 54(2), pp: 173-206.

DOI: https://doi.org/10.1093/oep/54.2.173

Friedemann-Sanchez, G. (2006) Assets in intra-household bargaining among women workers in Colombia's cut-flower industry, Feminist Economics, 12(1), pp: 247-260.

DOI: https://doi.org/10.1080/13545700500508551

Garcia, A. L. P. (2013) Market structure, conduct and performance of cut-flower growers in selected cities in Mindanao, Philippines, Asian Journal of Business and Governance, 03 (1), pp: 83-102.

DOI: https://doi.org/10.7828/ajobg.v3i1.346

Ghule, T. \& Menon, S. (2013) Scope and future of floriculture industry in India, Global Research Analysis, 2(2), pp: 27-28.

Grootaert, C. \& Bastelaer, T. (2001) Understanding and measuring social capital: a synthesis of findings and recommendations from the social capital initiative, Social Development Department Social Capital Working Paper Series, 45, Washington, DC: The World Bank.

Hewapathirana, G. I. (2011) The role of social identity in internationalization of women-owned small businesses in Sri Lanka, Journal Of Asia Business Studies, 5(2), pp: 172-193.

DOI: https://doi.org/10.1108/15587891111152339

Hulst. R. V. D. (2012) Sustainability in floriculture- BSC. Thesis Department of Management Studies, The Netherlands: University of Wageningen. 
Janko, A. M. \& Alemu, G. (2014) Supply and marketing of floriculture in Ethiopia, Unique Research Journal of Agricultural Economics and Rural Development, 1(2), pp: 9-24.

Janssens, W. (2010) Women's empowerment and the creations of social capital in Indian villages, World Development, 38 (7), pp: 974-988.

DOI: https://doi.org/10.1016/j.worlddev.2009.12.004

Ju, L. and Fu, X. (2012) The development of Scaling Table about inner social capital in technology innovation team and the test of its reliability and validity -based on empirical analysis of technology innovation teams in agriculture industry of Sichuan Province, Journal of Agricultural Science,4(8), pp: 124-135.

Kodagoda, T. (2013) Social issues and workplace culture: a case study in Sri Lanka, International Journal of Management and Enterprise Development, 12 (3), pp: 237-250.

DOI: https://doi.org/10.1504/IJMED.2013.054518

Manzoor, R., Shahid, S. A. \& Haqbqluch, M. U. (2001) Economics of floriculture in Pakistan: a case study of Lahore market, Pakistan Economic and Social Review, XXXIX(2), pp: 87-102.

Mathur, R. and Pachpande, P. (2013) Floriculture prospects and opportunities, International E Journal Management and IT, 13(1), pp: 1-10.

Matthee, M., Naude, W. and Viviers, W. (2014) Challenges for the floriculture industry in a developing country: a South African perspective, Development Southern Africa, 23 (4), pp: 511-528.

DOI: https://doi.org/10.1080/03768350600927326

Matthew, O. J., Rodriguez-Barraquer, T. and Tan, X. (2012) Social Capital and social quilts: network patterns of favor exchange, American Economic Review, 102(5), pp: 1857-1897.

DOI: https://doi.org/10.1257/aer.102.5.1857

Miller, M. C. (2012) Fresh cut flowers and exploitation, Perspective on Global Development and Technology, 11(01), pp: 88-98.

DOI: https://doi.org/10.1163/156914912X620752

Mou, N. H. (2012) Profitability of flower production and marketing system of Bangladesh, Bangladesh Journal of Agricultural Research, 37(1), pp: 77-95.

DOI: https://doi.org/10.3329/bjar.v37i1.11179

Munasib, A. B. A. \& Jordan, J. L. (2011) The effect of social capital on the choice to use sustainable agricultural practices, Journal of Agricultural and Applied Economics, 43(2), pp: 213-227.

DOI: https://doi.org/10.1017/S107407080000417X
Newbert, S. L. and Tornikoski, E. T. (2012) Supporter networks and network growth: a contingency model of organizational emergence, Small Business Economics, 39(01), pp: 141-159. DOI: https://doi.org/10.1007/s11187-010-9300-9

Niranjan, S. K. D. F. and Gunasena, H. P. M. (2006) Floriculture sector development programme: small and medium scale entrepreneurs in Sri Lanka, Sri Lanka Council for Agricultural Research Policy, pp: 1-49.

Noreen, S. (2011) Role of microfinance in empowerment of female population of Bahawalpur District, International Conference on Economics and Finance Research IPEDR,4 (1), pp: 23-37.

Padmini, S. M. P. C. (2014) Cut flower production, SL Magazine, 4 (1), pp: 22-27, Department of Government Information- Sri Lanka.

Rani, S. (2014 Entrepreneurial empowerment of women through Self- Help group, International Journal of Research in IT \& Management, 4(2), pp: 27-35.

Rao, V. \& Ibanez, A. M. (2005) The social impact of social funds in Jamaica: a 'participatoy econometric' analysis of targeting, collective action, and participation in communitydriven development, Journal of Development Studies, 41(5), pp: 788-838.

DOI: https://doi.org/10.1080/00220380500145297

Reid, N., Smith, B. W., Gatrell, J. D. \& Carroll, M. C. (2009) Importing change: Canadian competition and the U.S. floriculture industry, The Industrial Geographer, 1(6), pp: 3 18.

Rosener, J. B. (1990) Ways women lea, Harvard Business Review, 68 (6), pp: 119-125.

Shoji, M., Aoyagi, K., Kasahara, R., Sawada, Y. and Ueyama, M. (2012) Social capital formation and credit access: evidence from Sri Lanka, World Development, 40(12), pp: 2522-2536.

DOI: https://doi.org/10.1016/j.worlddev.2012.08.003

Sri Lanka (2010) National Policy Framework.

Sri Lanka, Central Bank (2013) Economic and Social Statistics of Sri Lanka, Colombo: Central Bank.

Sri Lanka, Department of Census and Statistics (2012) Sri Lanka Labour Force Survey- Annual Report.

Sri Lanka, Ministry of Agriculture (1997) Survey on the floriculture industry of Sri Lanka.

Sudhagar, S. (2013) Production and marketing of cut flower (Rose and Gerbera) in Hosur Taluk, International Journal of Business and Management Invention, 2 ( 5), pp: 15-25. 
Tripp, R.,Wijeratne, M. \& Piyadasa, V. H. (2005) What should we expect from Farmer Field Schools? A Sri Lanka Case Study, World Development, 33(10), pp: 1705-1720.

DOI: https://doi.org/10.1016/j.worlddev.2005.04.012

Uphoff, N. \& Wijeratne, C. M. (2000) Demonstrated benefits from social capital: the productivity of farmer organizations in Gal Oya, Sri Lanka, World Development, 28(11), pp: 1875 -1890 .

DOI: https://doi.org/10.1016/S0305-750X(00)00063-2

Wei, S., Joyce, D., Sar, S. \& Boas-Singomat, N. (2013) Developing floricultural supply-chain strategies- Papua
New Guinea case study, In Hicky G. (ed.) Socioeconomic Agricultural Research in Papua New Guinea. ACIAR Proceedings, No. 141, pp: 85-95, Canberra: Australian Centre for International Agricultural Research.

Zeb, J., Khan, Z. \& Khan, A. S. (2007) Marketing of floriculture in NWFP, Sarhad Journal of Agriculture, 23(3), pp: 815-816.

Zell, D., McGrath, C. and Vance, C. M. (2014) Examining the interaction of extroversion and network structure in the formation of effective informal support networks, Journal of Behavioral and Applied Management, 15(02), pp: 59-81. 